Fixed Point Theory, 22(2021), No. 2, 899-912

DOI: $10.24193 /$ fpt-ro.2021.2.59

http://www.math.ubbcluj.ro/ nodeacj/sfptcj.html

\title{
DISCUSSION OF HYBRID JS-CONTRACTIONS IN $b$-METRIC SPACES WITH APPLICATIONS TO THE EXISTENCE OF SOLUTIONS FOR INTEGRAL EQUATIONS
}

\author{
ORATAI YAMAOD* AND WUTIPHOL SINTUNAVARAT** \\ *Faculty of Sports and Health Science, Thailand National Sports University Suphanburi Campus, \\ Suphan Buri, 72000, Thailand \\ E-mail: oratai_eve@hotmail.com \\ ** Department of Mathematics and Statistics, Faculty of Science and Technology, Thammasat \\ University Rangsit Center, Pathum Thani 12120, Thailand \\ E-mail: wutiphol@mathstat.sci.tu.ac.th
}

\begin{abstract}
The purpose of this work is to introduce the new concept of a hybrid JS-contraction in $b$-metric spaces which includes various contractions in such spaces. The existence and uniqueness of a fixed point for self mappings satisfying the proposed contractive condition on $b$-metric spaces are studied. As an application, the existence result of a unique solution for integral equations is also given in order to illustrate the effectiveness of the obtained results.
\end{abstract}

Key Words and Phrases: Hybrid JS-contractions, $b$-metric spaces, integral equations.

2020 Mathematics Subject Classification: 47H09, 47H10.

Acknowledgement. The second author would like to thank the Thailand Research Fund and Office of the Higher Education Commission under grant no. MRG6180283 for financial support during the preparation of this manuscript.

\section{REFERENCES}

[1] A. Aghajani, M. Abbas, J.R. Roshan, Common fixed point of generalized weak contractive mappings in partially ordered b-metric spaces, Math. Slovaca, 4(2004), 941-960.

[2] I.A. Bakhtin, The contraction mapping principle in quasimetric spaces, Funct. Anal., Unianowsk Gos. Ped. Inst., 30(1989), 26-37.

[3] M. Boriceanu, M. Bota, A. Petruşel, Mutivalued fractals in b-metric spaces, Cent. Eur. J. Math., 8(2010), 367-377.

[4] M. Bota, A. Molnar, C. Varga, On Ekeland's variational principle in b-metric space, Fixed Point Theory, 12(2011), 21-28.

[5] L. Ćirić, Generalized contractions and fixed-point theorems, Publ. Inst. Math. (Belgr.), 12(1971), $19-26$.

[6] L. Ćirić, A generalization of Banach's contraction principle, Proc. Am. Math. Soc., 45(1974), 267-273.

[7] S. Czerwik, Contraction mappings in b-metric spaces, Acta Math. Inform. Univ. Ostraviensis, 1(1993), 5-11. 
[8] N. Hussain, V. Parvaneh, B. Samet, C. Vetro, Some fixed point theorems for generalized contractive mappings in complete metric spaces, Fixed Point Theory Appl., 185(2015).

[9] M. Jleli, B. Samet, A new generalization of the Banach contraction principle, J. Inequal. Appl., 38(2014).

[10] Z. Li, S. Jiang, Fixed point theorems of JS-quasi-contractions, Fixed Point Theory Appl., 40(2016).

[11] I.A. Rus, A. Petruşel, G. Petruşel, Fixed Point Theory, Cluj University Press, Cluj-Napoca, 2008.

[12] O. Yamaod, W. Sintunavarat, Fixed point theorems for $(\alpha, \beta)-(\psi, \varphi)$-contractive mapping in b-metric spaces with some numerical results and applications, J. Nonlinear Sci. Appl., 9(2016), $22-34$.

[13] O. Yamaod, W. Sintunavarat, Y. J. Cho, Common fixed point theorems for generalized cyclic contraction pairs in b-metric spaces with applications, Fixed Point Theory and Applications, 164(2015).

[14] O. Yamaod, W. Sintunavarat, Y. J. Cho, Existence of a common solution for a system of nonlinear integral equations via fixed point methods in b-metric spaces, Open Mathematics, 14(2016), 128-145.

Received: September 20, 2019; Accepted: January 7, 2020. 